TELAGA BAHASA

Volume 5

No. 1 Juni 2017

Halaman 143-158

\title{
KONSTRUKSI TUBUH DALAM CERITA PENDEK KERONCONG PEMBUNUHAN KARYA SENO GUMIRA AJIDARMA
}

\author{
(The Construction of Body in Short Story Entitled \\ Keroncong Pembunuhan by Seno Gumira Ajidarma)
}

\section{Uci Elly Kholidah}

S2 Ilmu Sastra, Fakultas Ilmu Budaya Universitas Gadjah Mada

J1. Sosiohumaniora 1 Bulaksumur Gedung Poerbatjaraka, Yogyakarta 55281.

Pos-el: ellyuci@gmail.com

\begin{abstract}
Abstrak
Penelitian ini berusaha menguraikan konstruksi tubuh yang terdapat dalam cerita pendek Keroncong Pembunuhan karya Seno Gumira Ajidarma menggunakan kerangka kerja ruang pascakolonial tubuh yang dicetuskan oleh Sara Upstone. Metode penelitian yang digunakan adalah metode pembacaan dekonstruktif. Hasil penelitian menunjukkan bahwa dalam cerita pendek ini, Seno Gumira Ajidarma tidak sepenuhnya menolak ruang yang solid namun tetap menampilkan ruang magis dan metaforis secara bersamaan.
\end{abstract}

Kata kunci: kolonial, pascakolonial, ruang tubuh, Upstone, Seno Gumira Ajidarma

\section{Abstract}

This study attempts to break down the construction of body which is consist on short story entitled Keroncong Pembunuhan by Seno Gumira Ajidarma by using postcolonial body proposed by Sara Upstone. Method of the study is deconstructive reading method. The result of this study shows that in this short story, Seno Gumira Ajidarma does not totally reject solid space but still serves the magical and metaphor space simultaneously.

Keywords: colonial, postcolonial, body, Upstone, Seno Gumira Ajidarma

\section{PENDAHULUAN}

Penjajahan yang terjadi di Indonesia selama ratusan abad tentu saja memberi efek signifikan di berbagai elemen. Tidak hanya di Indonesia, namun berefek pada semua negara yang pernah mengalami penjajahan. Sayangnya, hal itu bukan hanya dominasi 
politik negara penjajah kepada yang terjajah namun lebih kepada sesuatu yang bersifat hegemoni kultural yang pengaruhnya sudah mengakar kuat. Sastra sebagai produk budaya pastinya terkena dampak atas efek tersebut.

Sebagai negara bekas jajahan, Indonesia mengadaptasi serta mentransformasi berbagai hal dari negara penjajah. Dalam hal kesusastraan Indonesia, banyak karya sastra yang dapat dikaji berdasarkan ruang pascakolonial seperti halnya Tenggelamnya Kapal Van Der Wijck karya Hamka, Student Hijo karya Mas Marcokartodikromo, Jazz, Parfum, dan Insiden karya Seno Gumira Adjidarma, puisipusi karya Chairil Anwar, dan banyak karya sastra lainnya.

Fokus yang menjadi kajian pascakolonial bertumpu pada kondisi dan kecenderungan masyarakat yang terjajah dan pernah terjajah (Faruk, 2007: 16). Sedangkan indikasi yang dapat diketahui melalui tinjauan pascakolonial adalah bentuk perlawanan terhadap kekuasaan kolonial, ambiguitas atau ambivalensi sikap tokoh, mimikri, wacana identitas, oposisi baik secara struktur maupun wacana terhadap narasi dominan kolonial, konstruksi ruang kolonial, dan lain sebagainya (Rahariyoso, 2014: 43-44).
Kondisi dan kecenderungan yang dinyatakan Faruk di atas, salah satunya merujuk pada definisi masyarakat terjajah di mana pikiran, perasaan, sikap, perilaku, dan bahkan tubuhnya diduduki, dikuasai, diatur, dikontrol, dan dikendalikan oleh masyarakat penjajah melalui praktik, teori, dan sikap yang ditanamkan padanya oleh masyarakat penjajah itu (Faruk, 2007: 16). Dengan demikian, tubuh dapat menjadi indikasi fundamental atas jejak kolonial karena dalam konteks ini tubuh dianggap sebagai wilayah teritorial di mana penguasaan tubuh dianggap sebagai kunci untuk mempertahankan kuasa kolonial.

Dalam penelitian ini, pendekatan yang digunakan adalah ruang pascakolonial yang dikemukakan oleh Sara Upstone dalam bukunya yang berjudul Spatial Politics in the Postcolonial Novel (2009). Upstone berfokus pada politik ruang yang mana ruang tersebut akhirnya diklasifikasikan menjadi 5 tingkat meliputi bangsa, perjalanan, kota, rumah, dan tubuh. Lebih lanjut lagi, penelitian ini akan menggunakan ruang tubuh guna mengungkap konstruksi tubuh yang terdapat dalam cerita pendek Keroncong Pembunuhan karya Seno Gumira Ajidarma.

Seno Gumira Ajidarma -untuk selanjutnya akan disebut SGA- memulai karir menulisnya di usia 17 tahun. Keterlibatan Seno di dunia seni dimulai saat ia menjadi 
anggota rombongan sandiwara Teater Alam pimpinan Azwar A.N. Berawal dari dunia teater, SGA kemudian masuk ke dunia sastra. Karyanya yang pertama berbentuk puisi dimuat dalam rubrik "Puisi Lugu" dalam majalah Aktuil, asuhan Remy Sylado. Selanjutnya, Seno menulis cerpen dan esai. Cerpennya yang pertama "Sketsa dalam Satu Hari" dimuat dalam surat kabar Berita Nasional Tahun 1976. Esainya yang pertama dimuat dalam harian Kedaulatan Rakyat, Yogyakarta.

Menilik kisah kehidupannya selama masih remaja hingga beberapa peristiwa kontroversial yang melibatkannya, SGA adalah anak dari Prof. Dr. M.S.A Sastroamidjojo, seorang guru besar Fakultas MIPA Universitas Gadjah Mada. Dia memiliki pemikiran yang jauh berbeda dengan keluarganya. Jika keluarganya lebih memilih untuk hidup di lingkungan elite perumahan dosen Bulaksumur (UGM), rumah orangtuanya, SGA lebih memilih untuk melakukan pengembaraan setelah lulus SMP. Selama tiga bulan, ia mengembara di Jawa Barat, lalu ke Sumatera sampai akhirnya menjadi buruh pabrik kerupuk di Medan.

Tidak hanya lika-liku hidupnya yang kontroversial, namun dalam karirnya SGA tidak segan melakukan hal-hal di luar kebiasaan yang ada. Seperti saat ia menolak
Penghargaan Achmad Bakrie (PAB) bidang kesusastraan di tahun 2012. Sebuah pernyataan filosofisnya akhirnya menjawab alasan dari tindakannya tersebut.

Ada kalanya," ujarnya dengan mimik serius, "dunia politik menyentuh kita, sehingga saya atau kita harus bersikap..."

Sebagai seorang penulis, lanjutnya, pilihan "bertapa" di wilayah bernama menara gading, tidak dapat berlangsung selamalamanya.

Ada keputusan saya harus turun (dari menara gading). Ada titik tertentu tidak bisa menghindar lagi (dari politik). Sehingga (aktivitas melalui) tulisan saja, tidak cukup..." paparnya. (http://www.bbc.com/)

Menilik kisah hidup pernyataannya itu, SGA secara tidak langsung merupakan salah satu sastrawan yang tidak ingin terpaku dalam satu wacana. Dalam kajian pascakolonial hal ini berkaitan dengan ruang tubuh yang mana fluiditas ruang tubuh itu memberikan keheterogenan yang justru membuatnya tidak terjebak dalam wacana kolonial. Hal ini juga tercermin dalam cerita pendeknya yang berjudul Keroncong Pembunuhan.

Cerita pendek ini mengisahkan tentang seorang pembunuh bayaran yang tentu saja tugasnya adalah membunuh seseorang sesuai kesepakatan yang telah disetujui dengan kliennya. Untuk tugas kali 
ini dalam kurun waktu yang singkat, dia justru melakukan hal-hal di luar kesepakatan dan menggunakan senjatanya untuk mengancam dan menghabisi pihak yang tidak terduga tanpa instruksi dari kliennya. Berdasarkan penjelaskan yang terdapat di atas, maka permasalahan yang dirumuskan dalam penelitian ini adalah bagaimana konstruksi tubuh yang tercermin dalam cerita pendek Keroncong Pembunuhan karya Seno Gumira Ajidarma?

\section{LANDASAN TEORI}

Kolonial secara etimologis berasal dari bahasa Romawi "colonia" yang berarti tanah pertanian atau pemukiman. Pada dasarnya, kolonial tidak memiliki makna negatif seperti halnya penjajahan, penguasaan, pendudukan, atau konotasi eksploitasi lainnya. Citra negatif itu diperoleh setelah adanya interaksi tidak seimbang antara penduduk pribumi yang dikuasai dengan penduduk pendatang sebagai penguasa (Ratna, 2009: 205).

Wacana pascakolonial hadir setelah era kolonial berakhir secara fisik. Edward Said merupakan salah satu tokoh penting yang mencetuskan idenya tentang Barat dan Timur dalam bukunya yang berjudul Orientalism (1979). Setelahnya, muncul reaksi dari Homi K Babha yang menawarkan konsep ruang ketiga dan hibriditas serta menganggap bahwa apa yang disampaikan Said terlalu kaku, mutlak, dan sederhana (Mifthah, 2016: 13).

Pada tahun 2009, Sara Upstone memperkenalkan pembacaan pascakolonial yang menitikberatkan pada politik ruang. Dalam bukunya yang berjudul Spatial Politics in the Postcolonial Novel, Upstone menyatakan bahwasanya politik ruang tidak hanya terbatas pada bangsa saja, tapi justru mencerminkan berbagai macam ruang yang mengkonstruksi pengalaman pascakolonial.

This book offers a reading of the postcolonial novel that is centred upon an alternative concept of spatial politics: one that is rooted not solely in a politics of the nation, but instead reflects the diverse spaces that construct the postcolonial experience. (Upstone, 2009: 1)

Pengalaman kolonial dalam hal ini adalah pengalaman yang terjadi pada daerah yang pernah diduduki atau mengalami kolonialisasi Barat. Berkaitan dengan pengertian kolonialisme tentang penguasaan teritori, maka penguasa kolonial ingin menanamkan kekuasaan dan melestarikannya dengan berbagai strategi (Atikurrahman, 2014: 258).

Adapun strategi yang dilakukan oleh untuk melanggengkan kekuasaan mereka salah satunya yakni menciptakan ruang yang memiliki batas. Batas inilah yang akan 
membedakan akan kehidupan pribumi dan kehidupan kolonial. Undang-undang, agama, pendidikan, dan praktik sosial membuat kehidupan kolonial tampak superior terutama jika dibandingkan dengan kehidupan pribumi.

$$
\text { It is also crucial to the }
$$
perpetuation of colonial rule and the control of the colonial subject. For a boundary that appears as absolute cannot be undermined by local affiliations, a bounded territory must be respected as a legitimate entity: its status as an absolute undermines the preference for older communal or tribal practice. its laws, religion, education and social practice become superior. (Upstone, 2009: 5)

$$
\text { Upstone dalam bukunya }
$$
mengklasifikasikan 5 tingkat ruang dalam membaca pengalaman-pengalaman pascakolonial yang meliputi ruang bangsa, ruang perjalanan, ruang kota, ruang rumah, dan ruang tubuh.

Dalam penelitians ini, pembacaan ruang dalam hubungannya dengan teori pascakolonial seperti yang telah dikemukakan oleh Sara Upstone adalah membaca ruang tubuh yang dihadirkan oleh Seno Gumira Ajidarma dalam cerpennya yang berjudul Keroncong Pembunuhan.
Tubuh menjadi ruang paling mendasar yang penting dalam membaca jejak kolonialisasi. Upstone menyatakan:

...that postcolonial texts aim to magically reconfigure the body's significance in a way that marks the ultimate reduction of spatial scales, as the site of greatest colonisation becomes a resource facilitating the most powerful statements of resistance. (bahwa teks pascakolonial bertujuan untuk menyusun kembali makna penting tubuh secara luas sebagai bagian terakhir penurunan skala keruangan, tubuh merupakan situs terbesar kolonialisasi yang menjadi sumber untuk memfasilitasi pernyataan resistensi.) (Upstone, 2009: 147)

Dalam teks pascakolonial, tubuh juga dipahami sebagai wilayah teritori dan juga kunci untuk mempertahankan kontrol atas daerah jajahan. Tubuh tidak hanya dipahami mengalami represi dan kekerasan namun juga berbagai hal yang bersifat halus dan memberdayakan seperti halnya tulisan, pendidikan, dan praktik-praktik administratif. Semua hal tersebut dilakukan imperialisme untuk mengukuhkan superioritas dan kekuasan mereka atas wilayah jajahan.

...his emphasis on the control of bodies not only through 
violence, but also more subtle means of regulation, reflects a colonial discourse of the body which is not simply a story of beatings, rape and slavery. though these undoubtedly demand attention, the colonial maintenance of bodies is also a story of the propagation of bodily norms through writing, education and administrative practice. (Upstone, 2009: 147)

Lebih spesifiknya, jika kolonialisme berkaitan dengan perampasan wilayah maka perbudakan adalah perampasan kolonial atas tubuh di mana tubuh dianggap sebagai wilayah/teritorialnya. Dengan kata lain, tubuh juga dianggap sebagai properti (Upstone: 2009, 149). Perlakuan kolonial terhadap tubuh bertujuan mengukuhkan perlakuan di ruang-ruang yang lebih besar. Chaos dan hasrat (keinginan) juga diatur secara kaku, menggunakan sistem yang linear, meragukan, dan membedakan dalam rangka mewujudkan kehomogenan yang nantinya akan memudahkan kontrol kolonial terhadap wilayah jajahannya (Upstone: 2009, 150).

Ruang tubuh yang muncul dalam teks pascakolonial menawarkan pembacaan alternatif atas tubuh, menghadirkan tubuh yang ambigu di mana tubuh yang kaku tidak ditolak, namun di saat yang bersamaan juga memunculkan tubuh yang magis dan metaforis. Sebuah konsep yang tepat berdasarkan pemikian Upstone dalam rangka mewakili tubuh yang ambigu ini berasal dari konsep tubuh Plato. Tubuh di sini dilihat sebagai 'chora' (awalnya digunakan dalam konteks feminisme dan posstrukturalisme) (Upstone, 2009: 162).

Dalam pengertian lebih lanjut, chora adalah identitas cair yang dimiliki oleh tubuh, suatu usaha menolak belenggu atas batasan alamiah tubuh secara terus-menerus di mana batasan tersebut pastinya telah ditentukan oleh kolonial. Chora memungkinkan terjadinya chaos (diorder/ruang yang kacau) dalam wacana kolonial yang nantinya dianggap sebagai sesuatu yang berbahaya dan mengancam kekuasaan kolonial. Upstone (2009:15) menjelaskan post-space sebagai konsep yang berada di luar batas-batas kolonial maupun di luar batas-batas tradisi, bahkan melampaui atau berada sebelum batas-batas tersebut muncul; keadaan tersebut juga bisa dikatakan sebagai ruang hibrid yang cair dan ruang yang bergerak, sehingga tidak memiliki batas-batas lagi. Dengan mengutip Plato, Upstone (2009:162) menjelaskan bahwa chora adalah sesuatu yang menyediakan keadaan bagi berbagai benda untuk mengada. 
Konsep choric body sama dengan menggunakan metode pembacaan konsep Deleuzian body "tubuh tanpa organ" dekonstruksi. yang menolak perintah-perintah sosial dan hubungan keluarganya Freud, menentang bentuk definisi konvensional, sebagai sesuatu yang bukan laki-laki dan bukan perempuan dalam kepribadian seseorang, tetapi sebuah getaran, arus, schizzes, dan kumpulan (Upstone, 2009: 164). Tubuh yang cair meruntuhkan kekuasaan kolonial karena situasi tersebut menghentikan wacana stereotipe tubuh yang selama ini dicitrakan oleh kolonial dalam hubungannya antara penjajah dan terjajah (Upstone, 2009: 163164). Pada novel pascakolonial, bentuk realisme magis adalah alternatif bagi bentuk cair terhadap tubuh tersebut (Upstone, 2009: 165).

\section{METODE PENELITIAN}

Menurut Faruk, metode analisis data merupakan seperangkat cara atau teknik penelitian yang merupakan perpanjangan dari pikiran manusia karena fungsinya bukan untuk mengumpulkan data, melainkan untuk mencari hubungan antardata yang tidak akan pernah dinyatakan sendiri oleh data yang bersangkutan (Faruk, 2012: 25). Dengan demikian, data yang berhubungan dengan ruang pascakolonial tubuh dalam cerita pendek Keroncong Pembunuhan karya Seno Adapun metode pembacaan dekonstruktif itu, sesudah mengintrogasi teksnya, menghancurkan pertahananya, dan menunjukkan bahwa seperangkat oposisi berpasangan ditemukan di dalamnya. Oposisi itu tersusun secara hierarkis dengan menempatkan salah satu pasang sebagai yang istimewa. Dekonstruktor kemudian menunjukkan bahwa identitas yang istimewa itu tergantung pada pengeksklusiannya atas yang lain dan menunjukkan bahwa keutamaan justru terletak pada yang justru disubordinasikan (Faruk, 2012: 217). Pembacaan ini adalah cara kerja dekonstruksi yang digunakan dalam menganalisis ruang tubuh dan hal-hal di luar tubuh, yang teridentifikasi melalui satuan-satuan tekstual dalam objek material.

Dalam bukunya Metode Penelitian Sastra, Faruk (2013: 23) menyatakan bahwa dalam menguji hipotesis yang muncul maka diperlukan data-data empirik yang dianggap representatif lalu dianalisis hubungannya. Pertama, menentukan objek material dan selanjutnya adalah objek formal. Untuk penelitian ini, objek materialnya berupa cerita pendek berjudul Keroncong Pembunuhan karya Seno Gumira Ajidarma sedangkan objek formalnya yakni pembacaan Gumira Ajidarma akan diidentifikasi 
ruang tubuh dalam hubungannya dengan pascakolonialisme.

\section{METODE PENGUMPULAN DATA}

Dalam rangka menguji hipotesis yang merupakan hasil deduksi teoritik diperlukan data-data empirik yang diperoleh secara induktif yang kemudian harus dianalisis sehingga ditemukan hubungan antardata yang dianggap merepresentasikan hubungan antarfakta sebagaimana yang dinyatakan dalam teori dan hipotesis (Faruk, 2012: 2223).

Data dalam penelitian ini berupa satuan-satuan tekstual yang dikumpulkan dengan metode kajian pustaka, dengan objek material yang sudah disebutkan di atas. Datadata tekstual tersebut dapat berupa satuansatuan kata, tanda baca, frasa, atau pun rangkaian peristiwa yang terdapat dalam cerita pendek tersebut. Satuan-satuan tekstual tersebut diseleksi menurut konsep ruang pascakolonial tubuh, dengan melihat representasi konstruksi ruang tubuh dan halhal di luar ruang tubuh secara umum.

\section{METODE ANALISIS DATA}

Untuk analisis ini akan dilakukan pencarian satuan-satuan tekstual untuk melihat hubungan antara satuan-satuan tekstual yang signifikan di dalam cerita pendek Keroncong Pembunuhan karya Seno
Gumira Ajidarma yang sesuai dengan konsep ruang pascakolonial Upstone. Sebelum menentukan ruang pascakolonial yang ada, ruang konstruksi yang tersusun harus dilacak terlebih dahulu yang mana hal ini akan merepresentasikan keberadaan tubuh dan halhal di luar tubuh dengan ruang-ruang di sekitarnya.

Langkah selanjutnya yakni konstruksi tersebut dijelaskan bagaimana ruang tersebut mengatur tubuh, memosisikan tubuh, hingga upaya tubuh untuk keluar dari batas-batas yang diperoleh dengan cara membuat oposisi antara batas ataupun order dengan chaos. Selanjutnya konstruksi tubuh dan hal-hal di luar tubuh dilihat secara oposisional, apakah membentuk hubungan relasional dan hierarkies, mana yang dominan antara tubuh dan hal-hal di luar tubuh, untuk kemudian dijelaskan bahwa dominan tersebut menghancurkan yang lain secara hegemonik.

\section{HASIL DAN PEMBAHASAN}

Wacana kolonial selalu berusaha menghadirkan kehomogenan di berbagai skala ruang. Hal tersebut semata-mata dilakukan untuk melanggengkan kekuasaan kolonial atas warga pribumi yang memudahkan mereka untuk mengontrol. Teks-teks pascakolonial umumnya menolak hal ini dan justru menghadirkan keheterogenan sebagai alat resistensi. Hal ini 
juga yang tampaknya terdapat dalam cerita pendek Keroncong Pembunuhan karya Seno Gumira Ajidarma.

Paragraf pertama dalam cerpen ini menggambarkan seorang tokoh Aku yang memiliki keharusan membunuh orang. Tokoh Aku di sini juga menggunakan senapan dalam melancarkan pembunuhannya.

Lagu keroncong itu membuatku ngantuk, padahal malam ini aku harus membunuh seseorang. (Ajidarma, 1999: 3)

Lewat teleskop pada senapan ini, aku memperhatikan mereka satu per satu, seolah aku berada di antara mereka. (Ajidarma, 1999: 3)

Melalui kutipan pertama di atas dapat menunjukkan adanya kewajiban yang harus dilakukan Aku dengan membunuh orang. Kewajiban itu tentu saja tidak tiba-tiba hadir. Pasti ada subjek yang memberikan tugas/kewajiban agar Aku melakukan pembunuhan. Subjek yang memberikan tugas tersebut dapat dilihat melalui kutipan berikut:

Wanita bersuara halus yang memerintahku itu pun tentu cantik. Aku tak mengira seorang wanita akan terlibat dalam pembunuhan semacam ini. (Ajidarma, 1999: 4)

Adanya pihak yang memerintah dan diperintah dalam konteks ini dapat dianggap sebagai pihak yang berada dalam posisi penjajah dan terjajah. Di mana pihak penjajah bersifat superior yang dapat menentukan berbagai hal yang harus dilakukan oleh terjajah yang memiliki inferioritas. Tubuh terjajah menjadi barang/properti yang diperjualbelikan di mana ia harus melakukan perintah-perintah yang diwajibkan penjajah. Dalam cerita pendek ini, kontrak menjadi perantara antara penjajah dan terjajah. Melalui kontrak ini juga dapat dapat dilihat bagaimana wacana kapitalisme dan materialisme yang ditanamkan oleh penjajah kepada terjajah. Tentu saja, wacana yang demikian menghegemoni pihak terjajah dan justru diterima begitu saja tanpa ada perlawanan karena dianggap menjadi sesuatu yang natural/alamiah.

“Kamu sudah siap?” terdengar suara pada headphone itu, sebuah suara yang merdu

"Dari tadi aku sudah siap, yang mana orangnya?"

"Sabar dong, sebentar lagi." (Ajidarma, 1999:4)

“Siapa sasaranku?" tanyaku minggu lalu ketika dia memesan penembakan ini. Dilakukan lewat telepon seperti itu, tentu wajah hanya bisa dikira-kira saja.

"Kau tidak perlu tahu, ini bagian dari kontrak kita."

Kontrak semacam ini memang sering terjadi. Aku dibayar hanya untuk menembak, 
siapa yang jadi sasaran bukanlah urusanku. (Ajidarma, 1999:5)

Aku bisa tembak kalian dari sini juga tanpa tahu malu. Tapi aku tidak melakukan itu. Aku hanya bekerja berdasarkan kontrak. (Ajidarma, 1999:7)

Melalui kutipan di atas, dapat dianalisis juga bahwa terdapat upaya penciptaan batas-batas yang sedemikian rupa agar terjajah tetap berada dalam posisi tunduk. Dengan melakukan transaksi via telepon, hal itu menciptakan batasan yang mana memudahkan penjajah mengontrol terjajah dari jauh. Tentu saja hal tersebut menguntungkan bagi penjajah karena mereka tidak perlu hadir secara fisik namun pengaruhnya tetap dipatuhi dan mampu menghegemoni terjajah. Pada kutipan ketiga di atas, $A k u$ bahkan mengukuhkan sendiri peranan kontrak dalam relasinya dengan penjajah.

"Hei, kau masih disitu?" tiba-tiba terdengar lagi suara itu.

"Ya kenapa?"

"Jangan main-main! Aku tahu kamu tidak di tempat!"

Aku bergegas kembali ke teras.

"Bagaimana? Sudah datang orangnya?" (Ajidarma, 1999:7)

“Apakah harus kulakukan sekarang?”
"Nanti dulu, tunggu komando!" (Ajidarma, 1999:8)

\section{"Bagaimana? Sekarang?"}

Aku bilang tunggu perintah!"

Sialan cewek itu, berani benar membentak-bentak seorang pembunuh bayaran. (Ajidarma, 1999:9)

“Tunggu perintah apa lagi?"

"Kau tak perlu tahu, pokoknya tunggu!” (Ajidarma, 1999:9)

"Apa?" tanyaku lagi, karena ingin menyakinkan memang dia orangnya.

"Tembak sekarang!" (Ajidarma, 1999:10)

"Apa urusanmu tolol? Tembak dia sekarang atau kontrak kubatalkan!” (Ajidarma, 1999:11)

Beberapa kutipan di atas merupakan beberapa bentuk represi yang dilakukan pada tubuh terjajah di mana ia harus mengikuti semua yang diperintahkan dan aturan main yang telah ditetapkan. Semua itu tercermin dari penggunaan tanda seru di setiap akhir kalimatnya dan terdapat bagian di mana $A k u$ juga mengonfirmasi saat ia dibentak. Bahkan di kutipan terakhir, mereka yang berkuasa memaki dengan menggunakan kata tolol dan mengancam membatalkan kontrak. Situasi yang demikian itu memunculkan sebuah ruang yang kaku dan mutlak. Tidak hanya 
perlakukan yang dianggap bersifat represif namun juga pemberikan informasi bahwa target tembaknya adalah seorang pengkhianat bangsa dan negara juga merupakan tindakan memberdayakan dan mengontrol yang semata-mata dilakukan demi melanggengkan kekuasaan penjajah.

Teks-teks pascakolonial tidak sepenuhnya menolak tubuh yang kaku namun justru memunculkan tubuh yang ambigu di mana hal tersebut menghadirkan tubuh yang metaforis dan magis. Dalam proses membaca teks pascakolonial yang berfokus pada tubuh, muncullah chora yang bermakna identitas cair yang dimiliki oleh tubuh, suatu usaha menolak belenggu atas batasan alamiah tubuh secara terus-menerus di mana batasan tersebut pastinya telah ditentukan oleh kolonial. Pada cerpen ini di dalam tubuh $A k u$, identitas cair tersebut mulai terbentuk. Hal itu terdapat dalam kutipan berikut:

Dan aku mengamati wajah itu. Adakah ia mempunyai firasat? Dari balik teleskop ini, wajah-wajah memunculkan pesonanya sendiri, yang berbeda dibanding dengan bila kita berhadapan langsung dengan orangnya. Ia tak banyak bicara, namun tampaknya ia harus menjawab banyak pertanyaan. Dan aku merasa bahwa ia sangat hati-hati menjawab, wajahnya menunjukkan niat bersopan santun yang tidak menyebalkan. Apakah yang akan terjadi kalau ia kutembak mati? Aku teringat kematian Ninoy di Filipina...(Ajidarma, 1999: 8)

Tapi aku tidak tahu politik. Jadi, sambil menatap wajah yang akan berlubang itu, aku berpikir tentang yang lain. Mungkin ia punya istri, punya anak. Bahkan kupikir ia pun pantas punya cucu. (Ajidarma, 1999: 8)

Kedua kutipan di atas menggambarkan bagaimana tubuh $A k u$ merespons perintah, ia merasakan dan berpikir bukan hanya menerima perintah dan menjadi objek penjajah. Hal ini menunjukkan bahwa $A k u$ mulai memiliki keinginan memiliki yang membebaskan diri sendiri dan melakukan resistensi.

...Tanganku tiba-tiba bergerak sendiri menggeser senapan itu, dengan indra keenam kucari di antara kerumunan orang banyak. Wajah-wajah cantik silih berganti mengisi teleskopku. Aku harus memancingnya bicara.

Tunggu perintah apa lagi?

Kau tak perlu tahu, pokoknya tunggu! Ini tidak ada dalam perjanjian.

Ada! Kamu jangan main gila! (Ajidarma, 1999: 9)

...Rambutnya lurus dan hitam dengan poni menutup dahinya. Matanya menatap tajam ke arah si baju batik merah!

"Tembaklah dia sekarang," ujarnya pelan dalam head-phone-ku, dan kulihat dari teleskop dia memang berkata sendiri. 
Rupanya betul dia. Ia mendengar lewat giwang dan berbicara padaku lewat mikrofon yang tersembunyi dalam leontin kalungnya. (Ajidarma, 1999: 9)

Tindakan tubuh $A k u$ menggeser senapan, mencari, dan akhirnya menemukan orang yang menyuruhnya merupakan awal mula chaos. Hal-hal tersebut merupakan upaya penolakan atas belenggu yang dikonstruksi kolonial pada tubuh. Lebih lanjut lagi, tubuh $A k u$ lalu mempertanyakan tentang identitas target tembaknya pada perempuan yang mengontraknya. Tindakan chaos ini dipicu karena hadirnya konsep choric body yang memiliki kesadaran terhadap berbagai jejak kolonialisme yang ada. Hal itu dapat dilihat melalui kutipan berikut:

...Dan aku menatap mata orang itu. Astaga. Benarkan dia seorang pengkhianat?

"Kau tidak keliru? Benarkah ia seorang pengkhianat?"

"Tidak usah tanya-tanya, tembak sekarang!”

"Aku menatap lagi matanya, pengkhianat yang bagaimana?”

"Pengkhianat yang bagaimana? Kenapa tidak diadili saja?" (Ajidarma, 1999: 11)

Saat chaos terjadi, dalam wacana kolonial situasi ruang tubuh seperti itu dianggap sebagai sesuatu yang berbahaya dan mengancam kekuasaan kolonial. Hal ini terlihat pada kutipan cerpen berikut yang mana tubuh $A k u$ mampu membongkar seluk beluk perintah yang mungkin dikenali sebagai bentuk kolonialisme dan juga patriakal.

Perasaan aneh tiba-tiba merasuki diriku. Aku malah mengarahkan senapan pada wanita itu.

"Laras senapanku mengarah padamu manis," kataku dingin

“Apa-apaan ini?"

Dalam teleskop kulihat wajahnya mendongak ke arahku dengan kaget.

"Katakan padaku" kataku lagi, "apa kesalahan orang itu?"

"Tembak sekarang dia tolol atau kamu akan mati!"

"Justru kamu yang akan segera mati."

"Omong kosong! Kamu tak tahu di mana aku."

"Kau memakai cheongsam dengan belahan di paha, kamu ada di belakang orkes.

Dan kulihat wajahnya menjadi pucat

"Kamu sudah melanggar kontrak." (Ajidarma, 1999:12)

Tubuh $A k u$ tidak lagi berada di bawah kendali penjajah, ia menciptakan chaos yang dipicu oleh chora. Sebagai tubuh yang cair atau tidak bisa diprediksi, tentu saja ini membuat penjajah kesulitan mengontrol terjajah. Terutama jika sampai melakukan 
perlawanan yang merugikan kepentingan penjajah. Itulah alasan mengapa penjajah selalu menciptakan ruang kaku, batas-batas, aturan, kehomogenan, semua dilakukan dalam rangka mengukuhkan kekuasaannya terhadap yang terjajah.

Chaos berfungsi sebagai upaya pembongkaran terhadap pandangan yang dianggap tetap dan menanamkan pola-pola pemahaman serta pengalaman-pengalaman baru sehingga dibutuhkan fluiditas ruang yang tidak didapatkan dalam konsep kolonial maupun tradisi, atau dari konsep Barat dan Timur yang sudah dibatasi tersebut. Kondisi yang demikian memunculkan post-space (Rahariyoso, 2012: 31). Chaos menandakan tubuh tidak lagi bersifat pasif dan tanpa reaksi. Dalam cerpen ini, reaksi yang digambarkan tokoh $\mathrm{Aku}$ dinilai sebagai proses meruntuhkan segala kategorisasi yang bersifat kaku dan mutlak.

"Apa maumu?"

"Katakan kesalahannya."

"Ia pengkhianat, ia menjelek-jelekkan nama bangsa dan negara kita di luar negeri."

"Cuma itu?"

"Ia meresahkan masyarakat dengan pernyataan-pernyataan yang tidak benar.'

"Lantas?”

"Kau mau apa? Aku tidak tahu banyak"
"Aku ingin tahu, apakah semua ini merupakan alasan yang cukup untuk membunuhnya?"

"Itu bukan urusanmu. Ini politik."

"Urusanku adalah leontinmu manis, ia bisa pecah berantakan oleh peluruku, dan peluru itu tak akan berhenti di situ."

Wajah itu kembali menatap ke arahku dengan pandangan menghiba.

"Jangan tembak aku! Aku tidak tahu apa-apa!"

"Siapa menyuruhmu?"

"Aku tidak tahu apa-apa."

"Ah, jangan, jangan tembak!

Please..."

\section{"Siapa?"}

"Aku...aku bisa celaka."

"Sekarang pun kamu bisa celaka. Kuhitung sampai tiga. Satu...”

"Kamu gila, kamu merusak segalagalanya.”

"Dua..." Hmm, alangkah gugupnya dia.

"Ia ada di depan orang yang harus kamu tembak."

$$
\begin{aligned}
& \text { "Berkacamata?" } \\
& \text { "Ya." }
\end{aligned}
$$

Kuarahkan senapanku ke sana. Dan aku melihat orang itu...

Kubidikkan garis silang teleskopku ke jantungnya, sementara di telingaku 
mengiang suara penyanyi itu,...(Ajidarma, 1999: 12-14)

Melalui cerita pendek di atas, tubuh dinilai bukanlah entitas jasmaniah yang tidak memiliki peran apa pun dengan ruang di luar tubuh. Dengan demikian, tubuh melakukan berbagai proses resistensi, percampuran, dan saling memengaruhi dengan ruang di luar tubuh. Dualitas tersebut menghasilkan sebuah hubungan yang mana dalam cerita pendek ini terdapat relasi hierarkis antara tubuh dan ruang di luar tubuh.

Pada awalnya, tubuh diposisikan pada wilayah inferior di mana ia harus tunduk pada sebuah kekuasaan tertentu dan tentu saja diarahkan oleh penjajah yang berada di wilayah superior. Dalam cerpen ini terlihat saat $A k u$ menerima kontrak yang diajukan tokoh perempuan yang secara otomatis. Tubuh $A k u$ yang diarahkan itu pada akhirnya harus menjalankan tugas, dikontrol, diatur sehingga tubuh $A k u$ hanya dianggap sebagai sarana bagi sesuatu yang lain (dalam hal ini, terbunuhnya target tembak).

Dalam cerpen yang diteliti menggunakan ruang pascakolonial yang berfokus pada tubuh ini, tubuh $A k u$ mengalami apa yang disebut Upstone dengan choric body sehingga memunculkan chaos berupa melawan dan bahkan menghancurkan pihak penjajah superior yang tengah mengontraknya. Tubuh $A k u$ melakukan tindakan counterpoint yang memiliki pengaruh kuat terhadap ruang di luar tubuh hingga menghancurkan pihak terjajah. Hal itu sejalan dengan yang dinyatakan Upstone dalam bukunya bahwa tubuh tidak dianggap sebagai sesuatu yang hanya bisa menerima, tapi justru pemilik penuh atas dirinya sendiri yang dapat memicu perubahan dan pihak lainnya (Upstone, 2009: 170).

\section{SIMPULAN DAN SARAN}

Berkebalikan dengan kolonial yang menganggap tubuh adalah sebuah teritori dan properti, pascakolonial menganggap bahwa tubuh adalah suatu entitas yang otonom, yang cair, yang mampu memunculkan tubuh yang ambigu, dan dapat mendefinisikan dirinya sendiri secara bebas. Dengan menggunakan teori pascakolonial ruang tubuh yang dikemukakan oleh Sara Upstone, analisis yang dihasilkan adalah Keroncong Pembunuhan karya Seno Gumira Ajidarma tidak sepenuhnya menolak ruang yang solid namun tetap menampilkan ruang magis dan metaforis secara bersamaan. Ruang tubuh di sini juga dapat melakukan tindakan counterpoint yang memiliki pengaruh kuat terhadap ruang di luar tubuh (kesepakatan).

Saran untuk penelitian selanjutnya yang apabila menggunakan pendekatan serta objek material yang sama adalah melalui proses penguraian antara konstruksi tubuh 
dan ruang di luar tubuh yang terdapat dalam cerita pendek ini, peneliti diharapkan dapat mengaitkan temuan di atas dengan diskursusdiskursus lain yang mungkin hadir sehingga dapat mengetahui bagaimana konstruksi tubuh yang ingin ditawarkan oleh Seno Gumira Ajidarma dalam konteks yang lebih luas. 


\section{DAFTAR PUSTAKA}

Ajidarma, Seno Gumira. 1999. Penembak Misterius. Yogyakarta: Galang Press.

Atikurrahman, Moh. 2014. Prosa, Ruang, dan Kota Pascakolonial.

Yogyakarta: Poetika.

Faruk. 2007. Belenggu Pascakolonial:

Hegemoni dan Resistensi Sastra

Indonesia. Yogyakarta: Pustaka

Pelajar.

2012. Metode Penelitian Sastra:

Sebuah Penjelajahan Awal.

Yogyakarta: Pustaka Pelajar.

Miftah, Muhammad Yasif Femi. 2016. Novel

Mausimu Al-Hijrah Asy-Syamali

karya At-Thayyib Salih: Sebuah

Tinjauan Poskolonial. Yogyakarta:

Universitas Gadjah Mada.

Rahariyoso, Dwi. 2014. Paradoks Ruang

Tubuh Dalam Puisi "Sakramen"

Karya Joko Pinurbo: Kajian

'Pascakolonial Tubuh' Sara

Upstone. Yogyakarta: Poetika. , Dwi. 2015. Konstruksi Tubuh

dalam Antologi Celana dan Di Bawah Kibaran Sarung karya Joko Pinurbo. Yogyakarta: Universitas Gadjah Mada.
Ratna, Nyoman Kutha. 2009. Teori, Metode, dan Teknik Penelitian Sastra.Yogyakarta: Pustaka Pelajar.

Upstone, Sara. 2009. Spatial Politics in the Postcolonial Novel. England: Ashgate Publishing Limited.

http://www.bbc.com/indonesia/majalah/2012 /09/120903_tokoh_agustus2012_sen ogumiraajidarma.shtml diakses pada tanggal 15 Desember 2016.

http://ensiklopedia.kemdikbud.go.id/sastra/ar tike1/Seno_Gumira_Ajidarma diakses pada tanggal 15 Desember 2016. 